\title{
A Comparative Study of Hemispherical Solar Stills With Various Modifications to Obtain Modified and Inexpensive Stills Models
}

Mohammed El Hadi Attia

University of El Oued

abd elnaby kabeel ( $\nabla$ kabeel6@hotmail.com )

TANTA UNIVERSITY FACULTY OF ENGINEERING https://orcid.org/0000-0003-4273-8487

Mohamed Abdelgaied

Tanta University

Gamal B. Abdelaziz

Suez University

\section{Research Article}

Keywords: Hemispherical Solar Distillers, CuO-Water Nanofluid, Glass Cover Cooling, Cost, Productivity

Posted Date: February 17th, 2021

DOI: https://doi.org/10.21203/rs.3.rs-229464/v1

License: (c) (i) This work is licensed under a Creative Commons Attribution 4.0 International License.

Read Full License 


\section{Abstract}

This study is intended to comparative and analyze the operational performances of the conventional hemispherical solar still (CHSS), hemispherical solar still with glass cover cooling (HSS-C), and hemispherical solar still with CuO-water based nanofluid (HSS-N). To Obtain the best modifications that achieve the highest productivity with the lower inexpensive. The conventional hemispherical still (CHSS) was utilized as the reference case to investigate the best modification. In the first modification, $\mathrm{CuO}$ nanoparticles with three different concentrations $(0.1,0.2$, and $0.3 \%)$ were added to the basin water, to increase the intensity of absorbed solar energy, improve the thermal properties of basin fluid, and then increase the rate of vapor generation inside the distillation basin. In the second modification, water film glass cooling technology with three different flow rates $(1.5,2$, and $2.5 \mathrm{~L} / \mathrm{h})$ was utilized to increase the water vapor condensation rate. The experiments test of the three distillers (CHSS, HSS-N, and HSS-C) was conducted at the same weather conditions at $1 \mathrm{~cm}$ basin fluid depth. The average daily accumulative yield of CHSS is $3.85 \mathrm{~L} / \mathrm{m}^{2} /$ day, while the daily accumulative yield of HSS-N increases to $5.75,6.40$, and $6.80 \mathrm{~L} / \mathrm{m}^{2} /$ day with improvement $49.3,66.2$, and $76.6 \%$ at volume fraction $0.1,0.2$, and $0.3 \%$, respectively. Also, the daily accumulative yield of HSS-C increases to $4.9,5.35$, and $5.7 \mathrm{~L} / \mathrm{m}^{2} /$ day with improvements of $27.3,39$, and $48 \%$ at water film flow rates of $1.5,2$, and $2.5 \mathrm{~L} / \mathrm{h}$, respectively. The cost of distilled water produced from CHSS is $0.0106 \$ / \mathrm{L}$, while the utilization of HSS-C $(2.5 \mathrm{~L} / \mathrm{h})$ and HSS-N $(0.3 \%)$ reduces the cost of distilled water to 0.0072 and $0.0066 \$ / L$, respectively. Based on accumulative yield and economic analyzes, it is recommended that utilized the modified HSS-N ( $0.3 \%$ volume fraction) to achieving the highest accumulative yield and the lowest price of the produced distilled water.

\section{Introduction}

The world is striving to achieve development and progress in all fields. However, this development negatively affects nature. One of the important problems that is still being grappled with is the lack of fresh water. The developed countries have found a way to solve this dilemma, which is the use of electric energy to desalinate sea water, but the third world countries are still struggling to provide for their peoples' drinking water needs. Researchers have worked to develop different ideas and models to solve the problem of lack of safe drinking water in remote and isolated areas (Kabeel et al., 2018a, b; Kabeel et al., 2016; Kabeel and Abdelgaied, 2017a, b; Kabeel and Abdelgaied, 2019). The innovative designs of the solar stills, such as tubular, corrugated, pyramid, and hemispherical, these models have proven their effectiveness (Kabeel et al., 2017a; Kabeel et al., 2020a, b, c, d; Abdelgaied et al., 2020; El-Sebaii and Khallaf, 2020; Balachandran, et al., 2020a, b). Adding modifications to solar stills makes them more productive (Kabeel et al., 2019; Hassan et al., 2020; El-Said and Abdelaziz, 2020; Manokar et al., 2018; Attia et al., 2020, Al-Molhem and Eltawil, 2020).

Singh et al. (2020) concluded that the advancement of desalination purification innovations relied primarily on the highest quality of solar energy. Its progress may be interrupted by the dependence on technical aspects of the heat transfer properties. Mahian et al. (2017) studied adding a heat exchanger and using nanoscale fluids to improve the productivity of water produced from solar stills. The results 
showed that the use of heat exchanger with a temperature of more than $60^{\circ} \mathrm{C}$ is excellent and the addition of nanoparticles gives better productivity. Arunkumar et al. (2019) used nano-CuO coated with stainless steel and polyvinyl wipes in a solar still. Four solar stills were compared with an area of $0.5 \mathrm{~m}^{2}$. The first was by solar still alone, the second by using nanoparticles $\mathrm{CuO}$, the third by using polyvinyl wipes and the fourth by using nano-CuO and polyvinyl wipes. The results showed that the efficiencies of the four solar stills were $37 \%, 53 \%, 32 \%$ and $41 \%$ as mentioned above. Sharshir et al. (2018) compared the solar stills with graphite or copper oxide and conventional solar still. They found that the energy loss was proportional to the energy demolition within the additives (graphite and copper oxide). The result indicates that the efficiencies of the modified solar stills with graphite, copper oxide and conventional solar still are $41.18 \%, 38.61 \%$ and $29.17 \%$. Mahmoud et al. (2019) studied of impact of CuO nanoparticles and enriched with phase change materials in the performance SS solar still. For a percentage of $10 \%$ nano-CuO, at $\mathrm{h}=10 \mathrm{~cm}$ the highest yield obtained is about $11.6 \mathrm{~L} / \mathrm{m}^{2} /$ day, at $\mathrm{h}=0.2 \mathrm{~m}$ the outcome shows that the yield is $11 \mathrm{~L} / \mathrm{m}^{2} /$ day. Sharshir et al. (2019) studied of influence of nano- CuO and Carbon black in integrated pyramid solar still. The results showed that the use of carbon black produces an increase in distilled water by $34 \%$ and use nano-CuO produces an increase in distilled water by and $28 \%$. Shukla et al. (2019) investigated effect of $0.1 \%$ nano- $\mathrm{ZnO}$ and $33 \%$ concentrated $\mathrm{MgCl}$ liquid desiccant solution to attain the cooling effect in the upper basin in enhancement of SS solar still. The thermal efficiency of $19.2 \%$ when using nano-ZnO and a cooling stack of $0.162 \mathrm{~kW} / \mathrm{m}^{2}$. Malik et al. (2020) studied theoretically the performance of weir-type distiller with storage mediums. Mohaisen et al. (2020) empirically examined the influence of adding the condensing cavity on solar distiller yield. They found that the utilization of the condensing cavity improved the yield by $30 \%$. Sharshir et al. (2020) investigated the impact of carbon foam, exfoliated graphite flakes, and carbon foam and exfoliated graphite flakes on a yield of distiller with wick. Thakur et al. (2020) studied empirically the impact of Vtype concentrator on distiller yield. They conducted that use V-type concentrator coupled distiller improved the yield by $68.6 \%$.

The present experimental work aims to obtain the modified and inexpensive hemispherical solar distiller models. For this, we compared three hemispherical solar distiller, conventional hemispherical solar still (CHSS), hemispherical solar still with glass cover cooling (HSS-C), and hemispherical solar still with CuOwater based nanofluid (HSS-N). To Obtain the best modifications that achieve the highest productivity with the lower inexpensive. The conventional hemispherical still (CHSS) was utilized as the reference case to investigate the best modification. In the first modification, $\mathrm{CuO}$ nanoparticles with three different concentrations $(0.1,0.2$, and $0.3 \%)$ were added to the basin water, to increase the intensity of absorbed solar energy, improve the thermal properties of basin fluid, and then increase the rate of vapor generation inside the distillation basin. In the second modification, water film glass cooling technology with three different flow rates $(1.5,2$, and $2.5 \mathrm{~L} / \mathrm{h})$ was utilized to increase the water vapor condensation rate. The experiments test of the three distillers (CHSS, HSS-N, and HSS-C) was conducted at the same weather conditions at $1 \mathrm{~cm}$ basin fluid depth. The accumulative yield and economic analysis represent the two important factors to reach the adjustment that achieves the highest accumulative yield and the lowest price for the produced distilled water. 


\section{Experimental Setup And Procedure}

The present experimentations were conducted to get the best modification of hemispherical solar distillers that achieves the highest accumulative yield and the lowest price for the produced distilled water. From this vision, three different configurations of hemispherical solar distillers were designed, built, and tested: conventional hemispherical solar still (CHSS), hemispherical solar still with glass cover cooling (HSS-C), and hemispherical solar still with CuO-water based nanofluid (HSS-N). The conventional hemispherical still (CHSS) was utilized as the reference case to investigate the best modification. In the first modification, $\mathrm{CuO}$ nanoparticles with three different concentrations $(0.1,0.2$, and $0.3 \%)$ were added to the basin water, to increase the intensity of absorbed solar energy, improve the thermal properties of basin fluid, and then increase the rate of vapor generation inside the distillation basin. In the second modification, water film glass cooling technology with three different flow rates $(1.5,2$, and $2.5 \mathrm{~L} / \mathrm{h})$ was utilized to increase the water vapor condensation rate. Figures 1 and 2 show the schematic diagram and photographic view of the three hemispherical solar distillers (CHSS, HSS-C, and HSS-N).

For this purpose, three hemispherical basins, each $0.1 \mathrm{~m}^{2}$ in area, were made by making a circular cavity with a diameter of $38 \mathrm{~cm}$ and a depth of $3.5 \mathrm{~cm}$ within a $7 \mathrm{~cm}$ thick wooden board. A circular duct was made on the inner perimeter to collect the condensed water vapor on the plastic cover. This duct is connected to the product distillate water tank, and the inner surface was coated with the black silicone to prevent leakage and to increase the absorption rate of solar radiation. After that, the basin was covered with a hemispherical transparent plastic cover $3 \mathrm{~mm}$ thick and $40 \mathrm{~cm}$ in diameter. The thermal conductivity and density of this transparent plastic are $0.3 \mathrm{~W} / \mathrm{m} \mathrm{K}$ and $1270 \mathrm{~kg} / \mathrm{m}^{3}$, respectively.

In the HSS-N three different volume fraction of CuO-water nanofluid $(0.1,0.2$, and $0.3 \%)$ was studied. The CuO-water nanofluid was prepared, using $500 \mathrm{~W}$ Probe sonicator and $1 \%$ Ascorbic acid $\left(\mathrm{C}_{6} \mathrm{H}_{8} \mathrm{O}_{6}\right)$ as the surfactant. A two-week sedimentation test was utilized to check the stability and through this period observed that the nanoparticles are well dispersed.

In the HSS-C three different flow rate of cooling water $(1.5,2$, and $2.5 \mathrm{~L} / \mathrm{h})$ utilized to cool the glass cover was studied. To cool the casing, a sprinkler was installed on the top of the casing. This sprinkler was connected to the cooling water tank which contains a float valve connected to a makeup tube in order to stabilize the cooling water level inside this tank, and thus the rate of cooling water flow is constant throughout the test day.

The experiments were conducted on 6, 7, and 8 October 2020 in the southeast of Algeria $\left(06^{\circ} 47^{\prime} \mathrm{E}\right.$ and $33^{\circ} 30^{\prime} \mathrm{N}$ ). The experiments were conducted for 10 hours, through this period the depth of basin fluid kept constant at $1 \mathrm{~cm}$ for CHSS, HSS-N, and HSS-C, and the test was conducted in the same weather conditions. On the first test day, the HSS-N tested with a $0.1 \%$ volume fraction and HSS-C was tested with a $1.5 \mathrm{~L} / \mathrm{h}$ cooling water flow rate. On the second test day, the HSS-N tested with a $0.2 \%$ volume fraction and HSS-C was tested with a $2 \mathrm{~L} / \mathrm{h}$ cooling water flow rate. On the third test day, the HSS-N tested with a 
$0.3 \%$ volume fraction and HSS-C was tested with a $2.5 \mathrm{~L} / \mathrm{h}$ cooling water flow rate. Table 1 shows measurement devices, their accuracy, and standard uncertainties.

Table 1

Instruments, accuracy, and standard uncertainties

\begin{tabular}{|llll|}
\hline Devices & Range & Accuracy & Standard uncertainty \\
\hline Thermocouple & $0-100^{\circ} \mathrm{C}$ & $\pm 0.1^{\circ} \mathrm{C}$ & $0.07^{\circ} \mathrm{C}$ \\
\hline Solar Power Meter & $0-3999 \mathrm{~W} / \mathrm{m}^{2}$ & $\pm 10 \mathrm{~W} / \mathrm{m}^{2}$ & $6.78 \mathrm{~W} / \mathrm{m}^{2}$ \\
Scaled Vessel & $0-2000 \mathrm{ml}$ & $\pm 5 \mathrm{ml}$ & $0.8 \mathrm{ml}$ \\
\hline
\end{tabular}

\section{Results And Discussion}

To Obtain the best modifications for CHSS, HSS-N, and HSS-C that achieve the highest productivity with the lower inexpensive. The comparison was achieved in the same climate to ensure that the three solar stills were exposed to the same solar radiation at the same time. This similarity in operational conditions makes the comparison more accurate. Experiments were carried out from $8.00 \mathrm{AM}$ to $6.00 \mathrm{PM}$. Figure 3 shows the solar radiation $\left(\mathrm{W} / \mathrm{m}^{2}\right)$ in 6,7 , and 8 Oct. 2020 . Solar radiation intensity increases from morning to reach maximum between 12.00 and 13.00 and decreases till vanishes at nearly 18.00 (sunset). Maximum solar radiation was $1007 \mathrm{~W} / \mathrm{m}^{2}$. The three solar stills under study were exposed to the same solar radiation at the same time. Also, as presented in Fig. 4 the temperature of ambient air in the test location along the working period from 8.00 AM to $6.00 \mathrm{PM}$ was various between $28-44^{\circ} \mathrm{C}$, $29-$ $44{ }^{\circ} \mathrm{C}$, and $28-44^{\circ} \mathrm{C}$ on 6,7 , and 8 Oct. 2020 , respectively.

The basin water (or nanofluid) temperature versus time on 6, 7, and 8 Oct. 2020 was shown in Fig. 5 (a, b, and c) for the three different configurations of solar distillers under study. This figure shows that basin water (or nanofluid) temperature increases gradually from morning (nearly ambient temperature) till reaching a maximum within the period 1:00 PM till 3:00 PM with a delay about one hour from the peak of solar radiation. Also, this figure shows that the trend of basin water temperature for CHSS and HSS-C is almost the same and have the same values, but by add $\mathrm{CuO}$ nanoparticles to basin water (CuO-water nanofluid) in HSS-N, the basin temperatures will be increased with a ratio depends on the concentrations of $\mathrm{CuO}$ nanoparticles in nanofluid. Where the average improvement in the basin nanofluid temperature for HSS-N by adding $\mathrm{CuO}$ nanoparticles reached $4.7 \%, 9 \%$, and $12.7 \%$ for $\mathrm{CuO}$ nanoparticles concentrations $0.1,0.2$, and $0.3 \%$ respectively as compared to CHSS and HSS-C. Basin water temperatures for CHSS and HSS-C are very close to each other or nearly the same. This told that cover cooling has no effect on the basin water temperature while adding $\mathrm{CuO}$ increases it. As the nanoparticle concentration increases, water basin temperature increases due to absorptivity increasing, and then the generation rate of water vapor inside the basin increases with the increase in the concentrations of CuO nanoparticles. 
Figure 6 shows the variation of outside glass cover temperature of CHSS, HSS-N, and HSS-C in 6, 7, and 8 Oct. 2020. This figure shows that outside glass cover temperature increases gradually from morning (nearly ambient temperature) till reaching a maximum within the period 1:00 PM till 3:00 PM and starts to decrease again after this period. The outside glass cover temperatures for CHSS and HSS-N are very close to each other or nearly the same. This told that adding the CuO nanoparticles to basin water in HSS$\mathrm{N}$ has no effect on the basin temperature while adding glass cover cooling technology in HSS-C decreases it. Where the average reduction in the outside glass cover temperature for HSS-C by adding the water film glass cover cooling technology reached $11.4 \%, 13 \%$, and $17.8 \%$ for cooling-water flow rate 1.5 , 2, and $2.5 \mathrm{~L} / \mathrm{h}$, respectively as compared to CHSS and HSS-N. For HSS-C, a cooling water flow rate of 2.5 $\mathrm{L} / \mathrm{h}$ has the lowest glass temperature, this lower in outside glass cover temperature will increase the water vapor condensation rate.

Figure 7 shows the hourly variation of distillate yield for CHSS, HSS-N, and HSS-C through the operation time from 8:00 AM to 6:00 PM on 6, 7, and 8 Oct. 2020. As shown in this figure, in all operating conditions, distillate water increases gradually till reaching maximum at 2:00 PM with about two-hour delay from maximum radiation intensity. The maximum hourly distillate yield for CHSS reached 600 $\mathrm{mL} / \mathrm{m}^{2} \mathrm{~h}$ at 2:00 PM, while the maximum hourly distillate yield for utilization HSS-N improved to 850 , 950, and $1000 \mathrm{~mL} / \mathrm{m}^{2} \mathrm{~h}$ at 2:00 PM for CuO-water nanofluid concentration $0.1,0.2$, and $0.3 \%$, respectively. Also, for HSS-C, the maximum hourly distillate yield reached 750,800 , and $850 \mathrm{~mL} / \mathrm{m}^{2} \mathrm{~h}$ at 2:00 PM for cooling-water flow rates of $1.5,2$, and $2.5 \mathrm{~L} / \mathrm{h}$, respectively. Based on the analysis of hourly distillate yield for CHSS, HSS-N, and HSS-C, it is recommended that utilized the modified HSS-N (0.3\% volume fraction) to achieving the highest hourly distillate yield produced from the hemispherical solar distillers.

Fig. 8 presents the accumulative distillate yield for the three models CHSS, HSS-C, and HSS-N from 8:00 AM to $6: 00$ PM for $6^{\text {th }}, 7^{\text {th }}$, and $8^{\text {th }}$ Oct. 2020. As presented in Fig. 8, the average daily accumulative yield of CHSS is $3.85 \mathrm{~L} / \mathrm{m}^{2} /$ day, while the daily accumulative yield of HSS-N increases to $5.75,6.40$, and 6.80 $\mathrm{L} / \mathrm{m}^{2} /$ day with improvement $49.3,66.2$, and $76.6 \%$ at volume fraction $0.1,0.2$, and $0.3 \%$, respectively. Also, the daily accumulative yield of HSS-C increases to $4.9,5.35$, and $5.7 \mathrm{~L} / \mathrm{m}^{2} /$ day with improvements of $27.3,39$, and $48 \%$ at water film flow rates of $1.5,2$, and $2.5 \mathrm{~L} / \mathrm{h}$, respectively. Also, Fig. 9 shows a comparison between the accumulative distillate yield for the three models CHSS, HSS-C with three different flow rates $(1.5,2$, and $2.5 \mathrm{~L} / \mathrm{h})$, and HSS-N with three different concentrations of CuO-water nanofluid $(0.1,0.2$, and $0.3 \%)$. Based on the accumulative distillate yield analyzes presented in Figs. 8 and 9 , it is recommended that utilized the modified HSS-N (0.3\% volume fraction) to achieving the highest accumulative distillate yield.

\section{Economic Analysis}

A comprehensive economic study was conducted to calculate the cost of distilled water produced from the various modifications of hemispherical distillers to obtain the modified inexpensive model. The cost 
details of CHSS, HSS-C, and HSS-N are listed in Table 2 by used the steps outlined in Kabeel and Abdelgaied (2017b). As shown, the cost of $d$ freshwater produced from CHSS is $0.0106 \$ / L$, while the utilization of HSS-C $(2.5 \mathrm{~L} / \mathrm{h})$ and HSS-N $(0.3 \%)$ reduce freshwater cost to 0.0072 and $0.0066 \$ / \mathrm{L}$, respectively.

\section{Table 2}

Fabrication cost of the CHSS, HSS-C, and HSS-N.

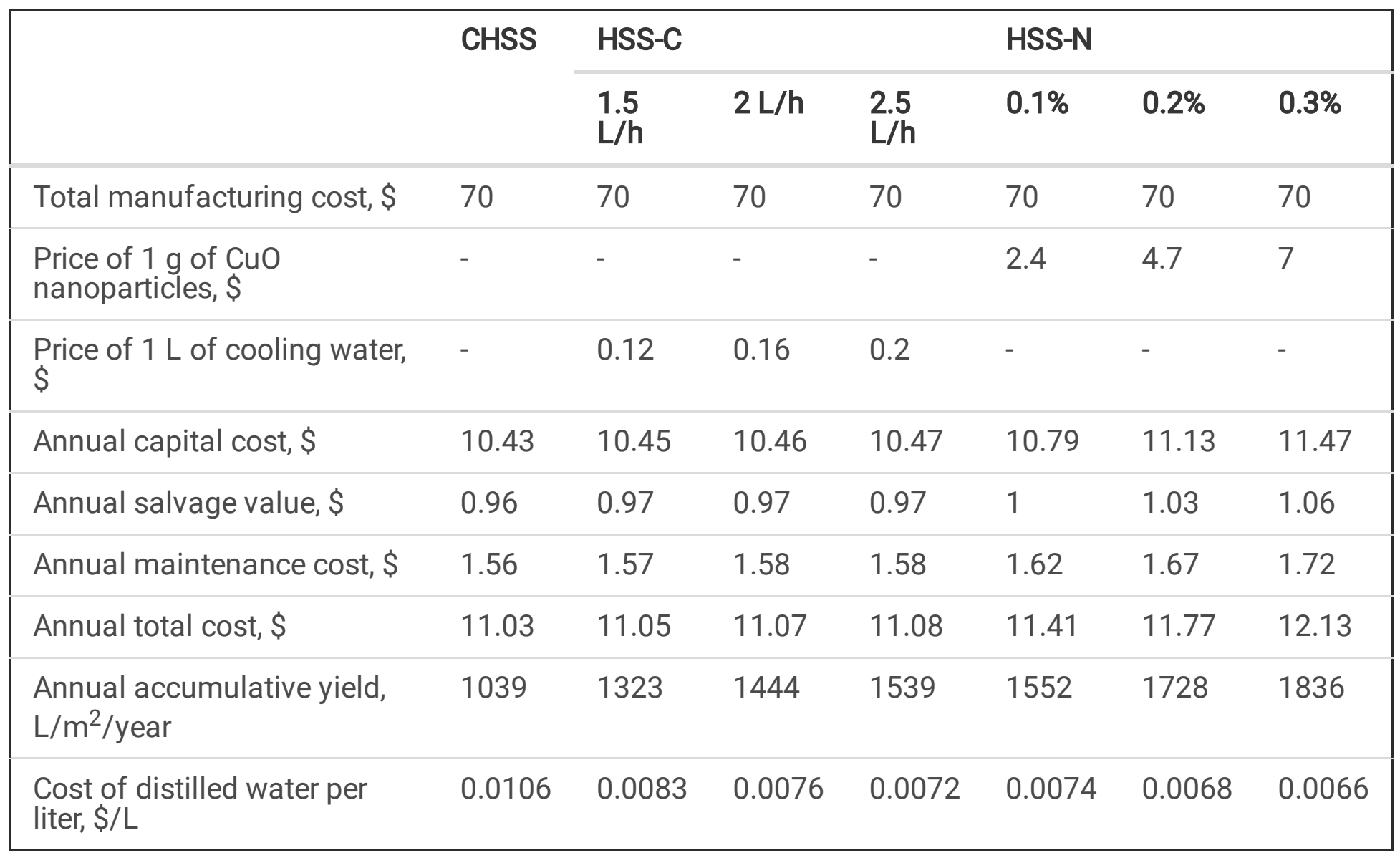

\section{Conclusions}

The aim of this study is to obtain the best modifications of hemispherical solar distiller that achieve the highest productivity with the lower inexpensive. We compared three hemispherical solar distillers; the first distiller is reference case (CHSS), the second contains CuO-water based nanofluid (HSS-N) with three different concentrations $(0.1,0.2$, and $0.3 \%)$, and the third cool the glass cover at a cooling water flow rate of $1.5,2$ and $2.5 \mathrm{~L} / \mathrm{h}$, respectively (HSS-C). Based on the experimental results, we conclude the following:

- The average daily accumulative yield of CHSS is $3.85 \mathrm{~L} / \mathrm{m}^{2} /$ day, while the daily accumulative yield of HSS-N increases to $5.75,6.40$, and $6.80 \mathrm{~L} / \mathrm{m}^{2} /$ day with improvement $49.3,66.2$, and $76.6 \%$ at volume fraction $0.1,0.2$, and $0.3 \%$, respectively. 
- The daily accumulative yield of HSS-C increases to $4.9,5.35$, and $5.7 \mathrm{~L} / \mathrm{m}^{2} /$ day with improvements of $27.3,39$, and $48 \%$ at water film flow rates of $1.5,2$, and $2.5 \mathrm{~L} / \mathrm{h}$, respectively as compared to CHSS.

- The cost of distilled water produced from CHSS is $0.0106 \$$ / L, while the utilization of HSS-C (2.5 $\mathrm{L} / \mathrm{h}$ ) and HSS-N (0.3\%) reduces the cost of distilled water to 0.0072 and $0.0066 \$ / L$, respectively.

Based on accumulative yield and economic analyzes, it is recommended that utilized the modified HSS-N ( $0.3 \%$ volume fraction) to achieving the highest accumulative yield and the lowest price of the produced distilled water

\section{Nomenclature}

\begin{tabular}{ll} 
SS & Single Slope \\
\hline CHSS & Conventional hemispherical distiller \\
\hline HSS-N & Hemispherical distiller with CuO-water based nanofluid \\
\hline HSS-C & Hemispherical Solar Still with glass cover cooling
\end{tabular}

\section{Declarations}

-Ethical Approval

Not applicable

-Consent to Participate

Not applicable

-Consent to Publish

Not applicable

-Authors Contributions

Mohammed El Hadi Attia: Conceptualization, experimental work, Writing - original draft, Writing. Mohamed Abdelgaied, Conceptualization, Investigation, Resources, , Writing -original draft, , Gamal. Abdelaziz-review \& editing,: Methodology, Investigation, Writing -original draft. Abd Elnaby Kabeel: Supervision, review \& editing

\section{Funding}

There is no funding used in this paper

-Competing Interests 
The authors declare that they have No competing interests

-Availability of data and materials

Not applicable

\section{References}

1. Abdelgaied M, Harby K, Eisa A, (2020). Performance improvement of modified tubular solar still by employing vertical and inclined pin fins and external condenser: an experimental study.

Environmental Science and Pollution Research. https://doi.org/10.1007/s11356-020-11585-3.

2. Al-Molhem YA, Eltawil MA, (2020) Enhancing the double-slope solar still performance using simple solar collector and floatable black wicks. Environ Sci Pollut Res 27: 35078-35098.

3. Arunkumar T, Murugesan D, Raj K, Denkenberger D, Viswanathan C, Rufuss DDW, Velraj R, (2019). Effect of nano-coated CuO absorbers with PVA sponges in solar water desalting system. Applied Thermal Engineering 148: 1416-1424.

4. Attia MEH, Driss Z, Kabeel AE, Abdelgaied M, Manokar AM, Sathyamurthy R, Hussein AK, (2020). Performance Evaluation of Modified Solar Still using Aluminum Foil Sheet as Absorber Cover- a Comparative Study. Journal of Testing and Evaluation (JTE), (in press), 2020. https://doi.org/10.1520/JTE20200249.

5. Balachandran GB, David PW, Mariappan RK, Kabeel AE, Athikesavan MM, Sathyamurthy R, (2020a) Improvising the efficiency of single-sloped solar still using thermally conductive nano-ferric oxide. Environ Sci Pollut Res 27: 32191-32204.

6. Balachandran GB, David PW, Vijayakumar ABP, Kabeel AE, Athikesavan MM, Sathyamurthy R, (2020b) Enhancement of PV/T-integrated single slope solar desalination still productivity using water film cooling and hybrid composite insulation, Environmental Science and Pollution Research 27:32179-32190

7. El-Said EMS, Abdelaziz GB, (2020). Experimental investigation and economic assessment of a solar still performance using high-frequency ultrasound waves atomizer, Journal of Cleaner Production 256:120609.

8. El-Sebaii A, Khallaf $A E$, (2020) Mathematical modeling and experimental validation for square pyramid solar still. Environ Sci Pollut Res 27: 32283-32295.

9. Hassan H, Yousef MS, Ahmed MS, Fathy M, (2020) Energy, exergy, environmental, and economic analysis of natural and forced cooling of solar still with porous media. Environ Sci Pollut Res 27: 38221-38240.

10. Kabeel AE, Abdelgaied M, Eisa A, (2018a) Enhancing the performance of single basin solar still using high thermal conductivity sensible storage materials. Journal of cleaner production 183: 20-25.

11. Kabeel AE, Abdelgaied M, Almulla N, (2016). Performances of pyramid-shaped solar still with different glass cover angles: experimental study, 7th International Renewable Energy Congress 
(IREC). IEEE 1-6.

12. Kabeel AE, Abdelgaied M, (2017a). Performance enhancement of modified solar still using multigroups of two coaxial pipes in basin, Applied Thermal Engineering 118: 23-32.

13. Kabeel AE, Abdelgaied M, (2017b). Observational study of modified solar still coupled with oil serpentine loop from cylindrical parabolic concentrator and phase changing material under basin, Solar Energy 144: 71-78.

14. Kabeel AE, Abdelgaied M, (2019). Performance enhancement of a photovoltaic panel with reflectors and cooling coupled to a solar still with air injection, Journal of Cleaner Production 224, 40-49

15. Kabeel AE, Teamah MA, Abdelgaied M, Abdel-Aziz GB (2017a) Modified pyramid solar still with vcorrugated absorber plate and PCM as a thermal storage medium. Journal of Cleaner Production 161: 881-887.

16. Kabeel AE, Harby K, Abdelgaied M, Eisa A, (2020a). Performance of the modified tubular solar still integrated with cylindrical parabolic concentrators, Solar Energy 204: 181-189.

17. Kabeel AE, Harby K, Abdelgaied M, Eisa A, (2020b). Augmentation of a developed tubular solar still productivity using hybrid storage medium and CPC: An experimental approach, Journal of Energy Storage 28: 101203..

18. Kabeel AE, Harby K, Abdelgaied M, Eisa A, (2020c). A comprehensive review of tubular solar still designs, performance, and economic analysis, Journal of Cleaner Production 246: 119030.

19. Kabeel AE, El-Agouz E, Athikesavan MM, Ramalingam RD, Sathyamurthy R, Prakash N, Prasad C, (2020d) Comparative analysis on freshwater yield from conventional basin-type single slope solar still with cement-coated red bricks: an experimental approach. Environ Sci Pollut Res 27: 3221832228.

20. Kabeel AE, El-Agouz ES, Athikesavan MM, Ramalingam RD, Sathyamurthy R, Prakash N, Prasad C, (2019) Comparative analysis on freshwater yield from conventional basin-type single slope solar still with cement-coated red bricks: an experimental approach. Environmental Science and Pollution Research, 1-11.

21. Kabeel AE, El-Samadony YAF, El-Maghlany WM, (2018b). Comparative study on the solar still performance utilizing different PCM, Desalination 432: 89-96.

22. Mahian O, Kianifar A, Heris SZ, Wen D, Sahin AZ, Wongwises S, (2017). Nanofluids Effects on the Evaporation Rate in a Solar Still Equipped with a Heat Exchanger. Nano Energy 36: 134-155.

23. Mahmoud A, Ookwara HFS, Ahmed M, (2019). Influence of partial solar energy storage and solar concentration ratio on the productivity of integrated solar still/humidification-dehumidification desalination systems. Desalination 467: 29-42.

24. Manokar AM, Winston DP, Kabeel A E, Sathyamurthy $R$, (2018). Sustainable fresh water and power production by integrating PV panel in inclined solar still. Journal of Cleaner Production, 172: 27112719.

25. Malik MZ, Musharavati F, Khanmohammadi Saber, Khanmohammadi Shoaib, Nguyen DD, (2020). Solar still desalination system equipped with paraffin as phase change material: exergoeconomic 
analysis and multi-objective optimization. Environmental Science and Pollution Research. https://doi.org/10.1007/s11356-020-10335-9

26. Mohaisen HS, Esfahani JA, Ayani MB, (2020). Effect of condensing cavity on the performance of a passive solar desalination system: an experimental study. Environmental Science and Pollution Research. https://doi.org/10.1007/s11356-020-10866-1

27. Sharshir SW, Elsheikh AH, Ellakany YM, Kandeal AW, Edreis EMA, Sathyamurthy R, Thakur AK, Eltawil MA, Hamed MH, Kabeel AE, (2020). Improving the performance of solar still using different heat localization materials. Environmental Science and Pollution Research (2020) 27:12332-12344

28. Sharshir SW, Elsheikh GPAH, Edreis EMA, Eltawili MA, Abdelhamidj T, Kabeel AE, Zang J, Yang N, (2018). Energy and exergy analysis of solar stills with micro/nano particles: a comparative study. Energy Conversion Manage. 177: 363-375.

29. Sharshir SW, Kandeal AW, Ismail M, Abdelaziz GB, Kabeel AE, Yang N, (2019). Augmentation of a pyramid solar still performance using evacuated tubes and nanofluid: Experimental approach. Appl. Thermal Engg. 160: 113997.

30. Shukla DL, Modi KV, (2019). Hybrid solar still-Liquid desiccant regenerator and water distillation system. Solar energy 182: 117-133.

31. Singh AK, Singh DB, Dwivedi VK, Tiwari GN, Gupta A, (2020). Water purification using solar still with/without nano-fluid: A review. Materials Today: Proceedings 21: 1700-1706.

32. Thakur AK, Sharshir SW, Ma Z, Thirugnanasambantham A, Christopher SS, Vikram MP, Li S, Wang P, Zhao W, Kabeel AE, (2020). Performance amelioration of single basin solar still integrated with $V$ type concentrator: Energy, exergy, and economic analysis. Environmental Science and Pollution Research. https://doi.org/10.1007/s11356-020-10625-2.

\section{Figures}




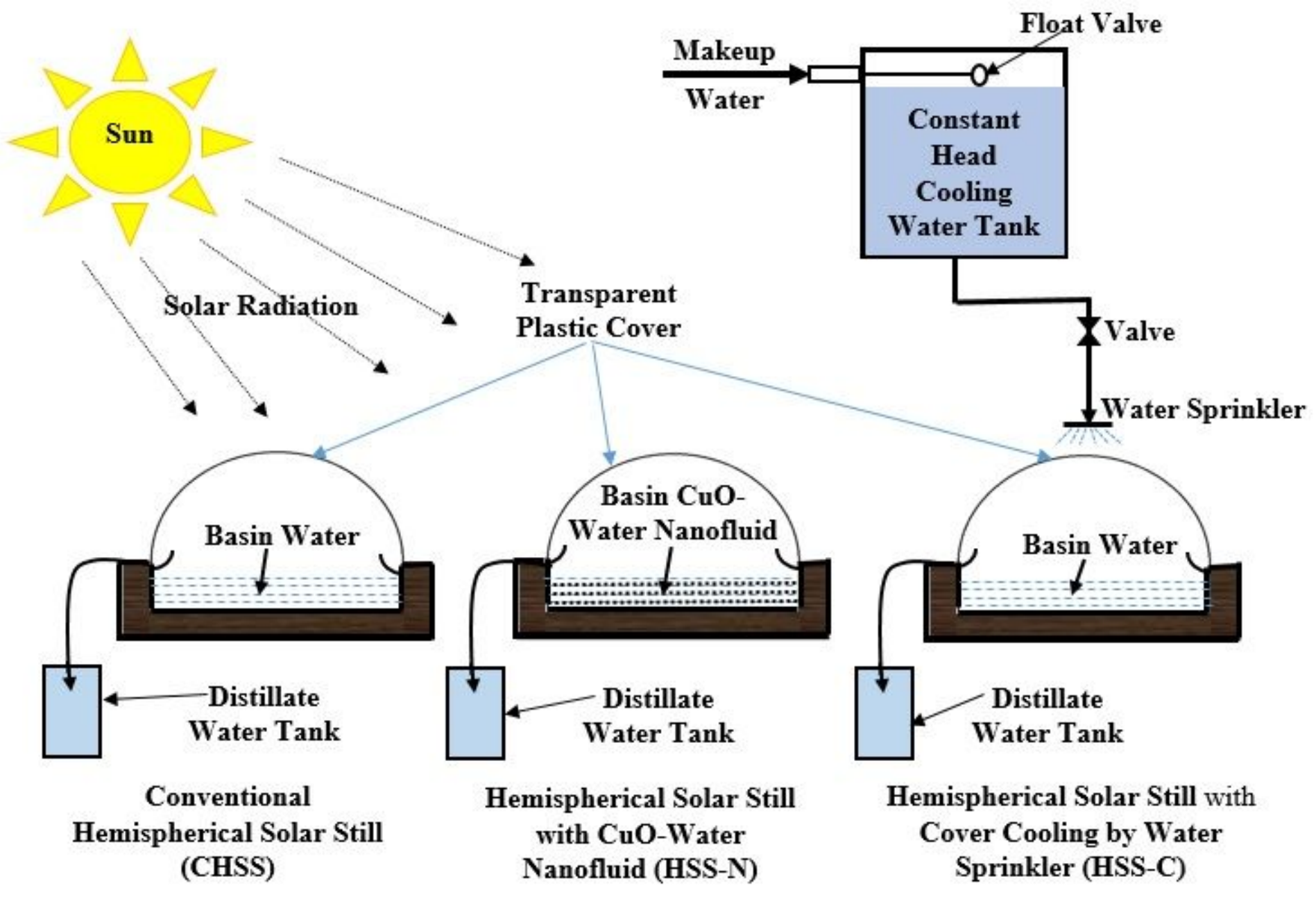

Figure 1

Schematic diagram of the three hemispherical solar distillers (CHSS, HSS-C, and HSS-N)

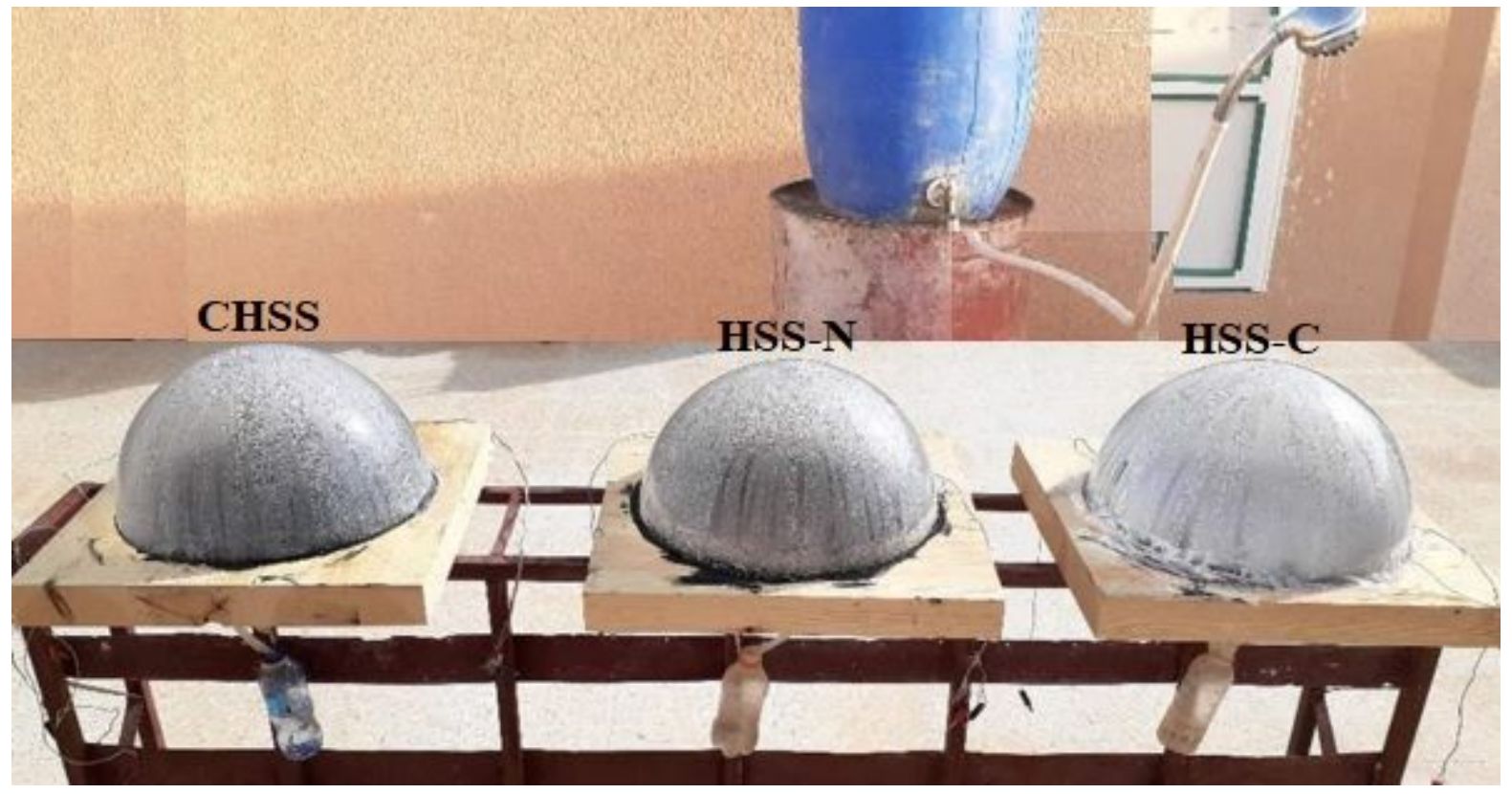

Figure 2 
Photo of three hemispherical solar distillers (CHSS, HSS-C, and HSS-N)

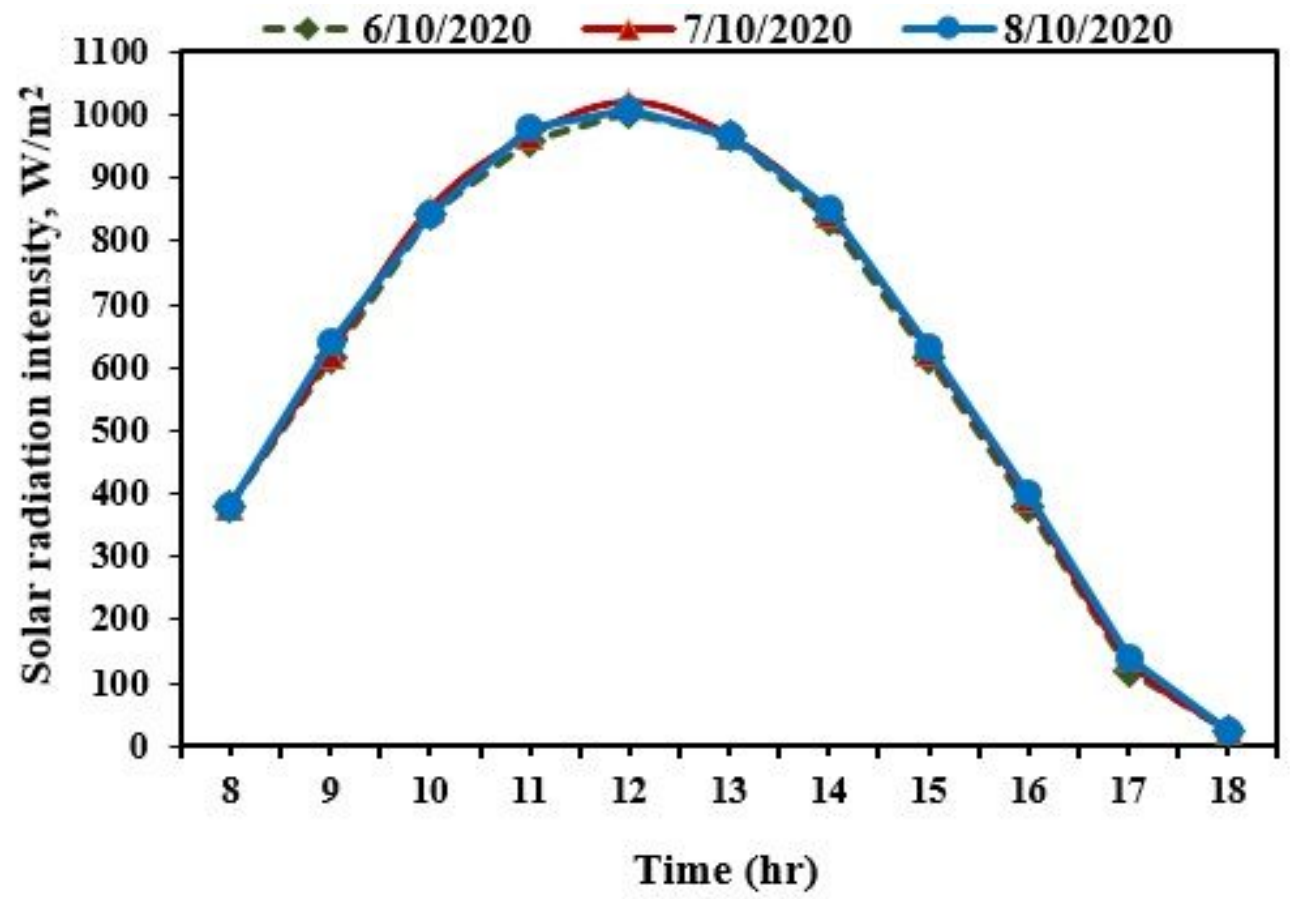

Figure 3

Variation of solar radiation intensity in 6, 7, and 8 Oct. 2020

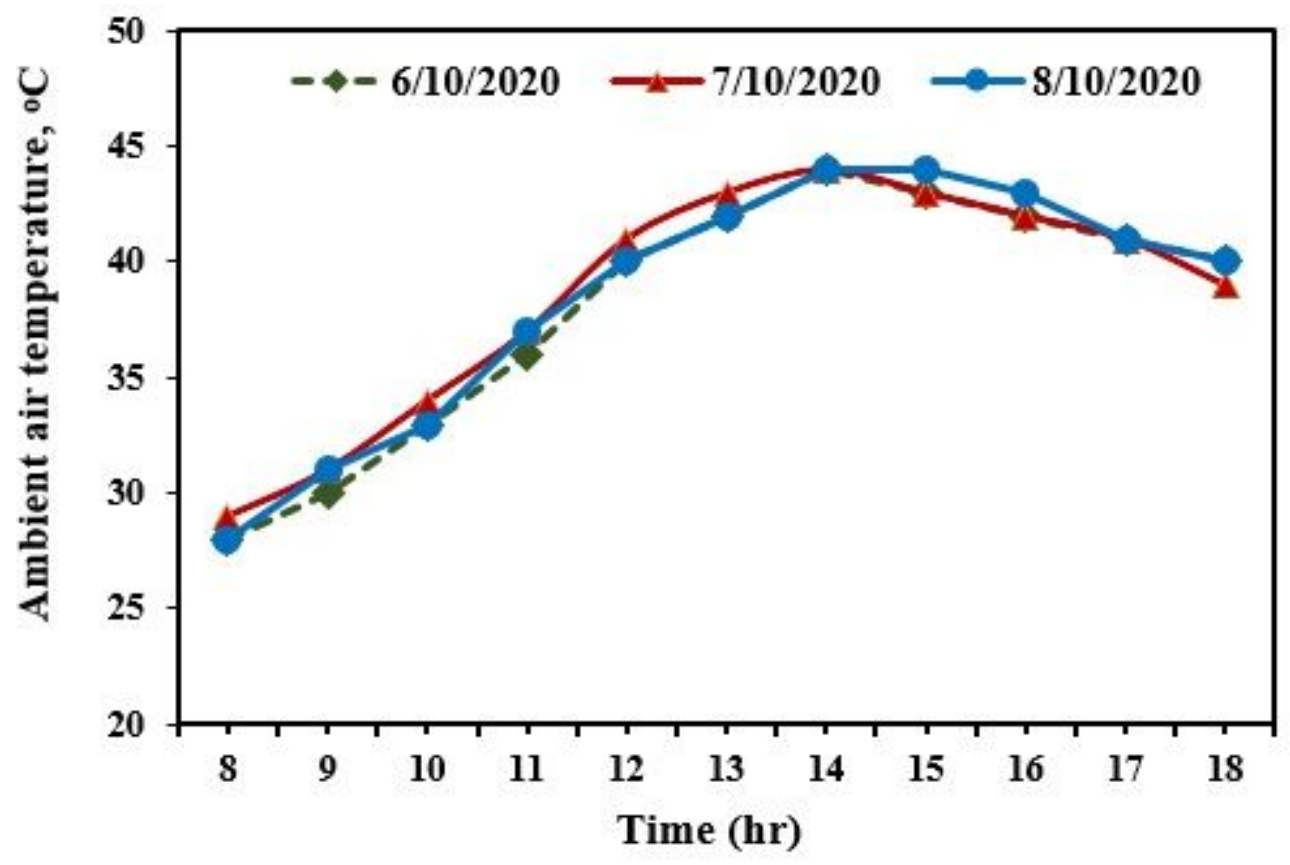

Figure 4

Temperature variation of ambient air in 6, 7, and 8 Oct. 2020 

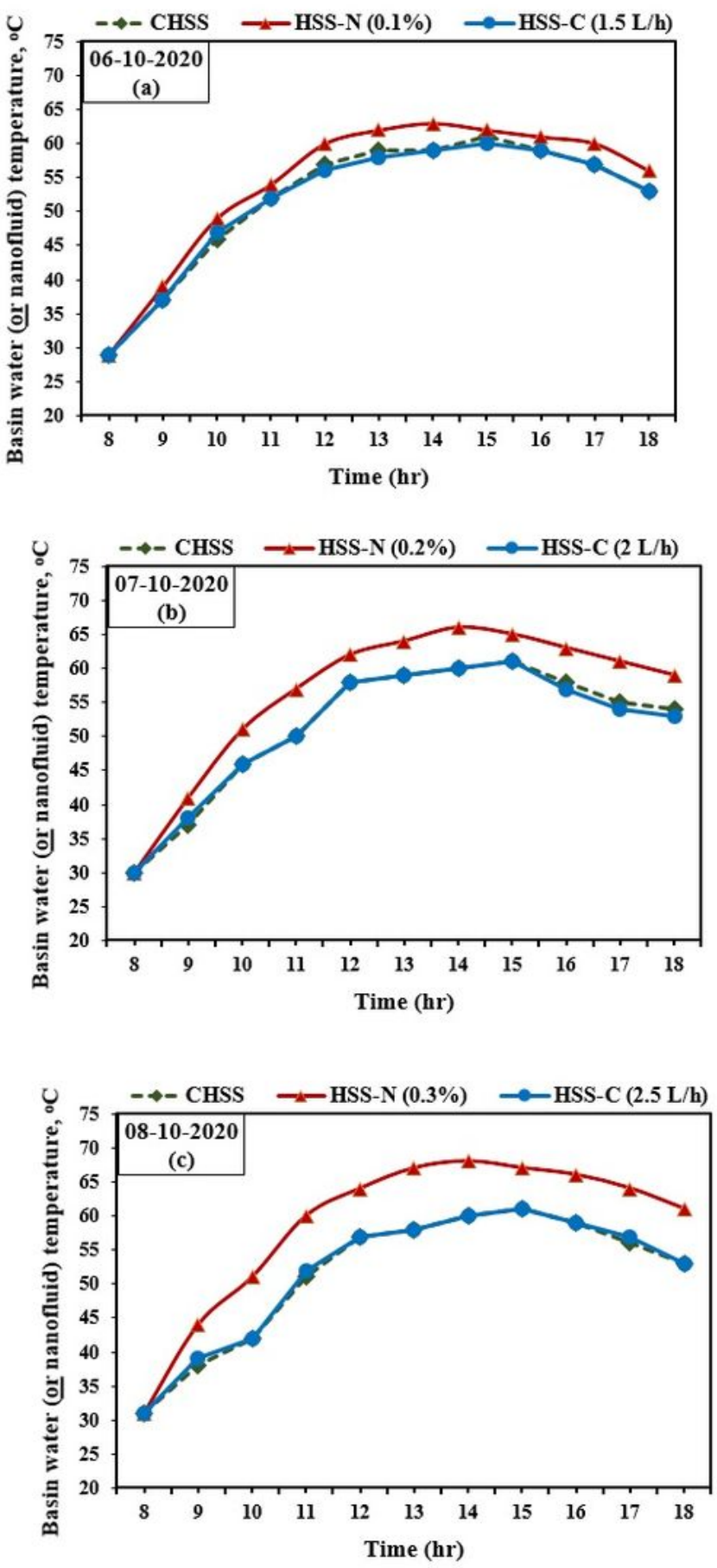

Figure 5

Temperature variation of basin water (or nanofluid) for three distillers in 6, 7, and 8 Oct. 2020 

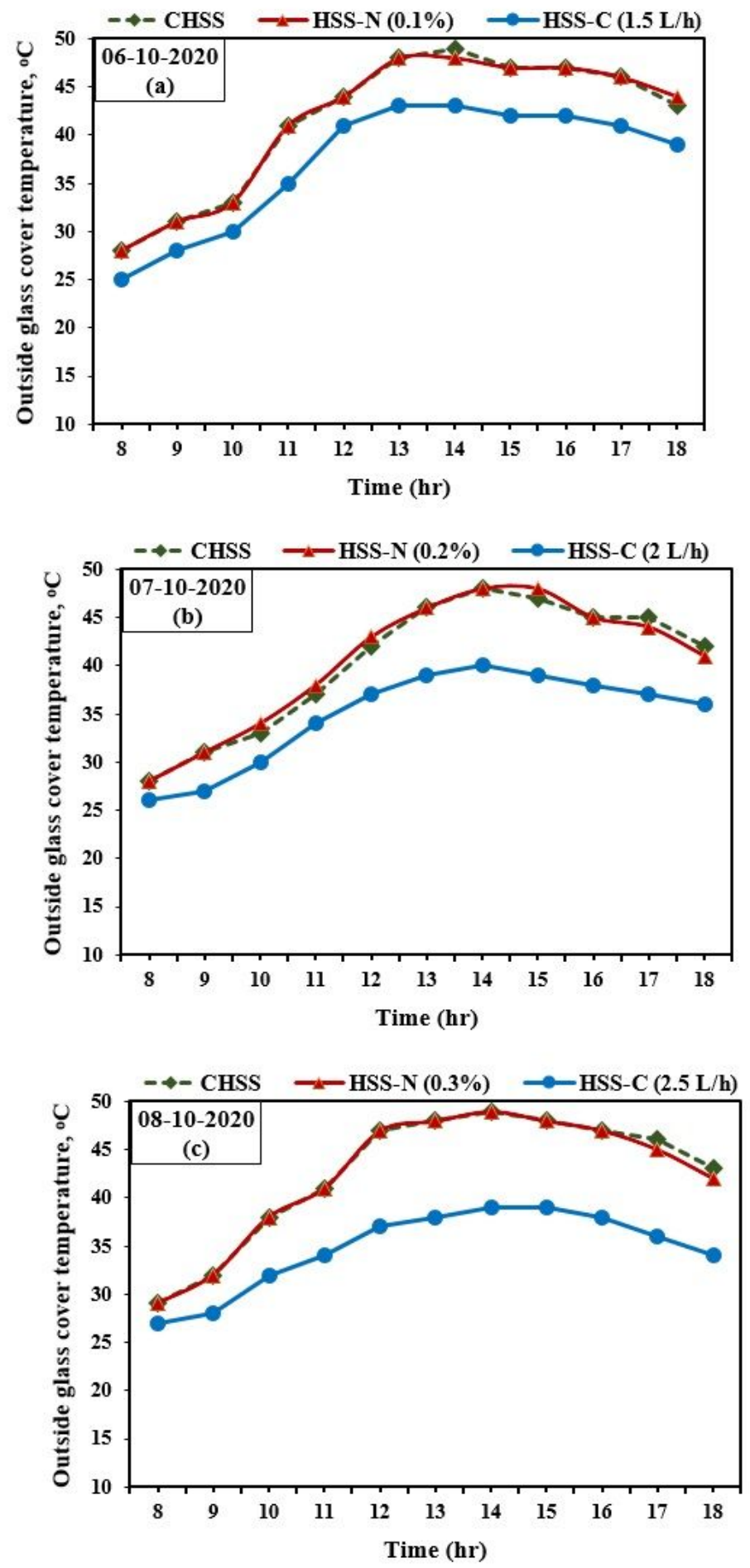

\section{Figure 6}

Temperature variation of outside glass for three distillers in 6, 7, and 8 Oct. 2020. 

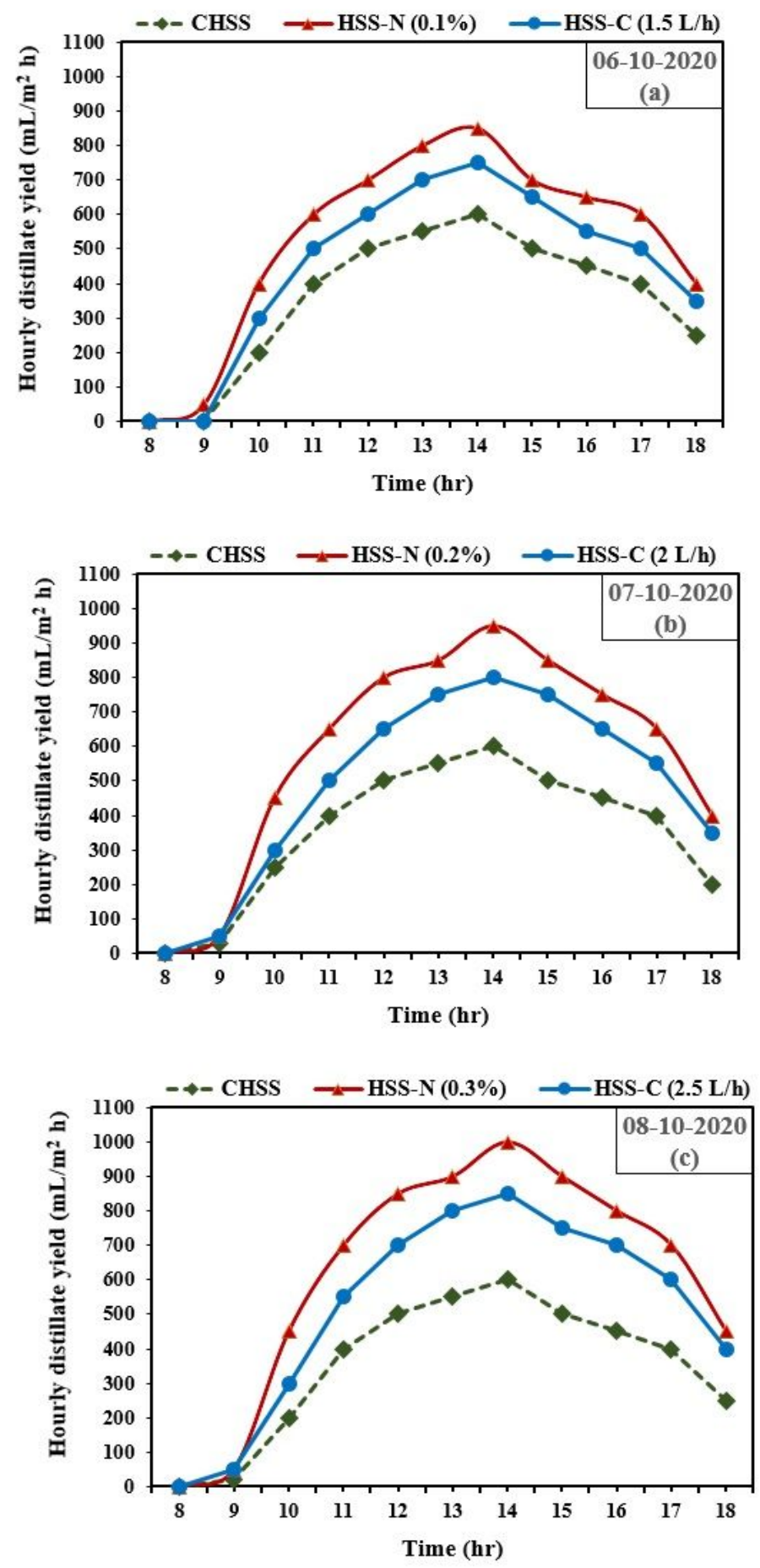

\section{Figure 7}

Hourly distillate yield through the operation time for CHSS, HSS-N, and HSS-C. 

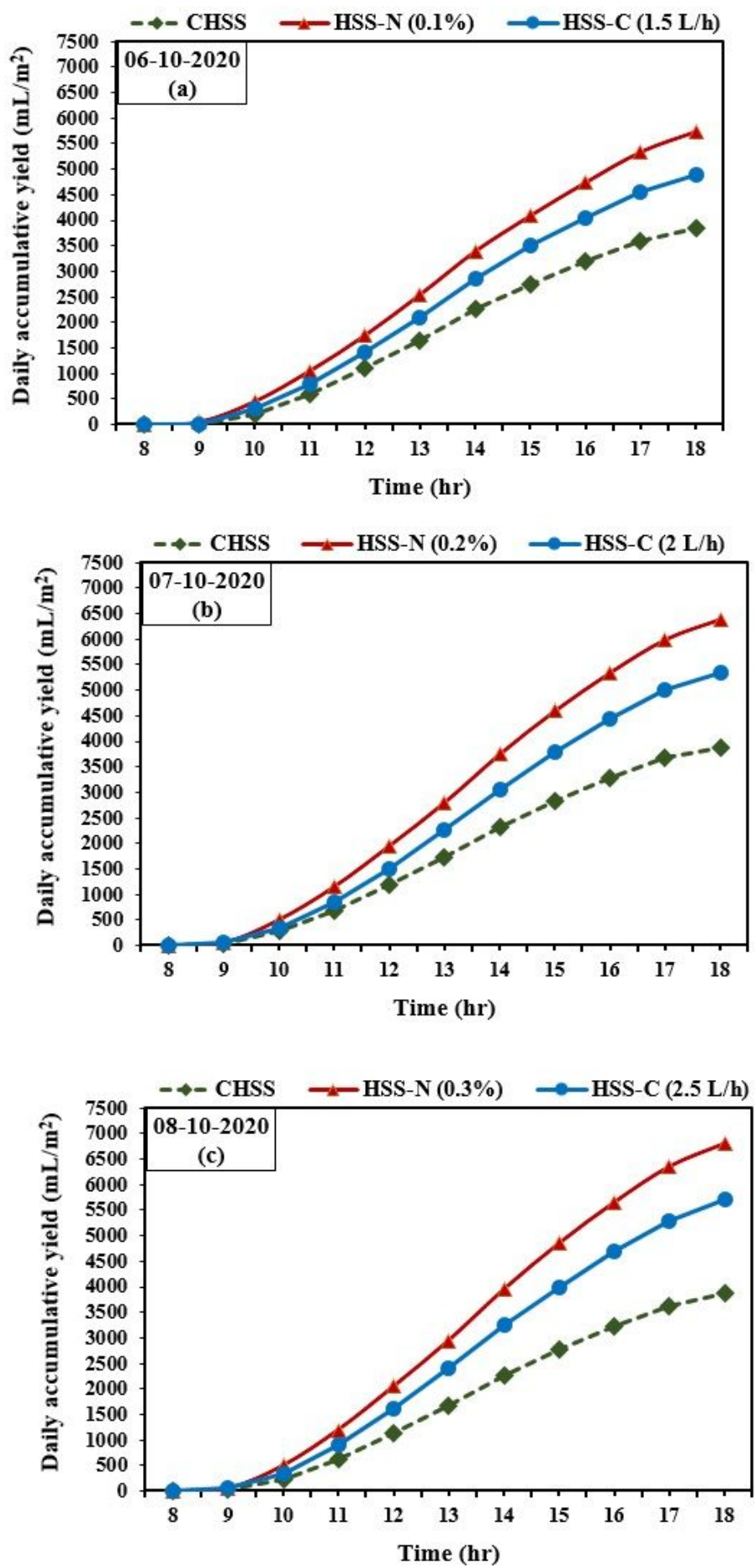

Figure 8

Accumulative distillate yield for the three models CHSS, HSS-C, and HSS-N. 


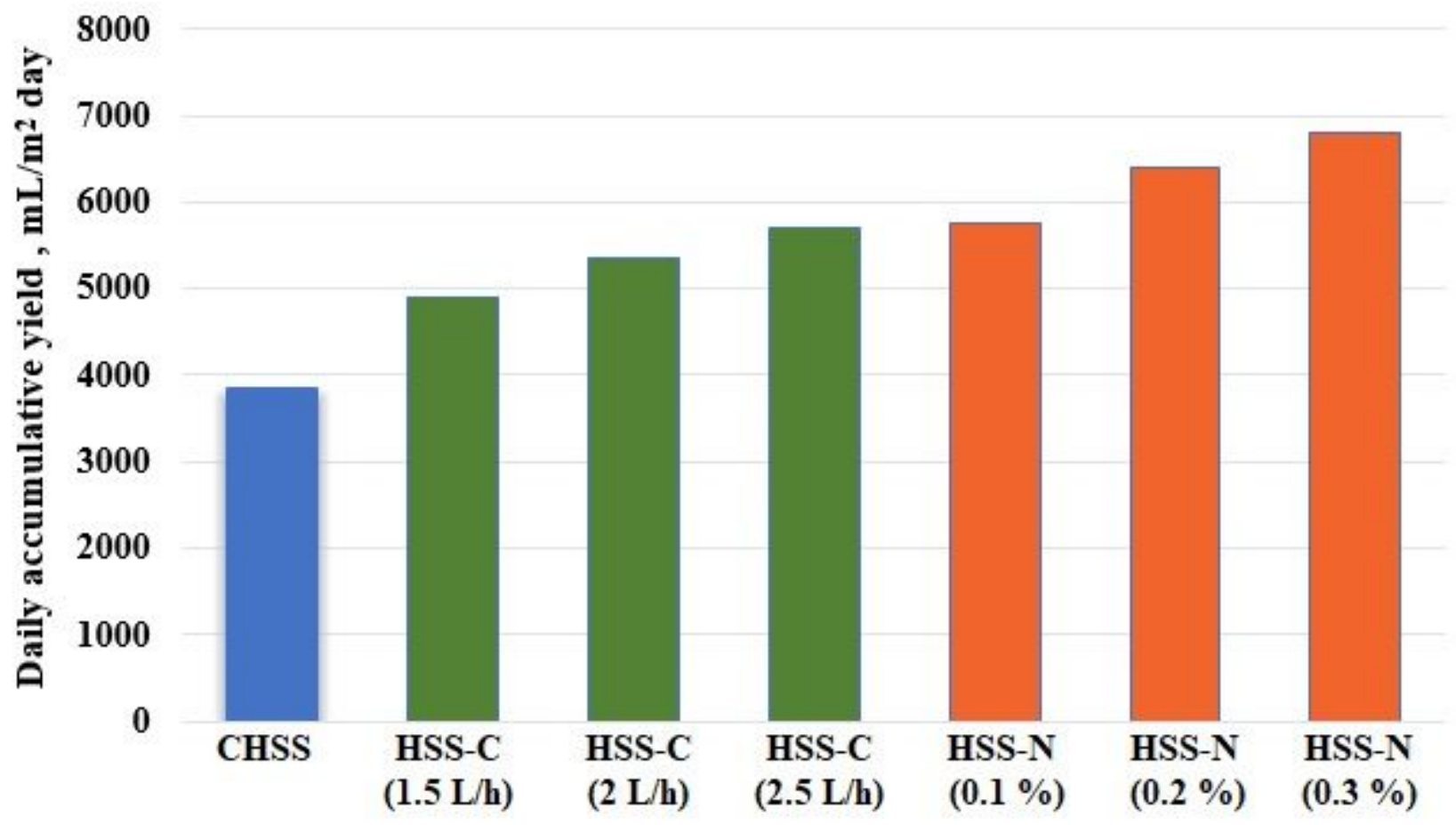

Figure 9

A comparison between the accumulative yield for the three models CHSS, HSS-C, and HSS-N with different operating conditions. 